\title{
The roles of indigenous missionaries and Christians in the expansion of Christianity in Nigeria, 1860-1969
}

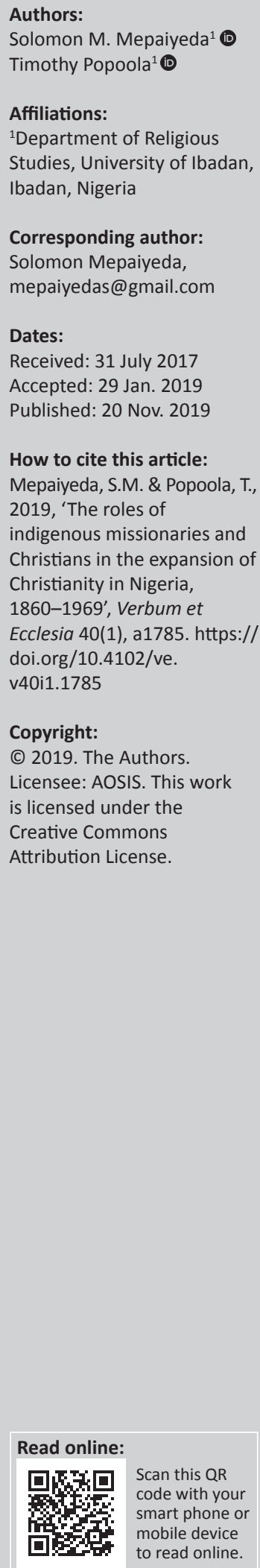

The contextual perspective that this article challenges is the neglect of significant contributions of indigenous African missionaries and Christians by some early missionary historiographers whose writings largely focused on European missionaries. This created a lacuna in the proper documentation of African missionary enterprises. The research will not only serve as a platform to discover the socio-religious importance of past African Christian heroes of Nigerian origin but also provide additional information on existing African historiography not from the perspective of Europeans but Africans, using both theological and scientific approaches with the aim of presenting more accurate records in church history. This will serve as a biography of African Christianity.

Intradisciplinary and/or interdisciplinary implications: This article has intra- and interdisciplinary implications for African philosophy, African traditional religion and ethics because most theories and views of Africans in these fields are yet to be largely researched to bring into the limelight their relevance to African realities.

Keywords: indigenous missionaries; expansion of Christianity; Adedeji Okuseinde; Walter Bako; Nigeria.

\section{Introduction}

A critical study of the history of Christianity in Nigeria reveals an interesting picture of a venture that has the record of both success and failure. Although Christian religion gained solid footing in some areas and thrived in other areas, there was futility of efforts that majority of church historians attributed, among other factors, to the resistance from adherents of traditional religion and Islam.

However, a noticeable factor underlying the stunted growth of the works of European missionaries in Nigeria in the 18th and 19th centuries was the neglect of indigenous missionaries whom the white missionaries discriminated against because of their erroneous view that Nigerians and Africans (in general) lack the acumen or charisma for leadership. The dearth of these indigenous personnel in missionary work resulted in the confinement of missionary activities to townships, because the hinterlands were initially neglected. This accounted for lack of initial presence of the church in most areas, whereas the said townships were already enjoying some benefits that came with Christianity.

Another problem discovered is that it seems church historians of all generations over-concentrated their works on the white missionaries, while the missionary activities of some of the Nigerians who collaborated with the former were not given much attention. Apart from people like Samuel Ajayi Crowther, Babamuboni and few others, a reader of the history of Christianity in Nigeria would be tempted to assume that the success of missionary activities rests solely on the white missionaries because the efforts of their Nigerian counterparts were not given adequate attention in history. Hence, Mukuka mentioned the irony that in the history of the mainline churches only the profiles of the European missionaries were highlighted, while reference to indigenous clergy was infrequent and almost always anonymous (Mukuka 2006:213).

This research work, therefore, is predominantly an attempt to document the lives and efforts of key indigenous missionaries in Nigeria who participated in the expansion of Christianity and those Christians whose legacies have remained indelible in the history of Christianity in Nigeria. The project searchlight focuses on southwestern and north central Nigeria, being the first recipients of Christianity in the country, with Revd Canon James Adedeji Okuseinde (Oyo State) and Evangelists John Olubobokun (Ekiti State) and Thomas Bako (Kogi State) constituting the first set of personalities to be considered now. However, in the nearest future, adequate attention 
will be given to other indigenous workers in the mission field from other regions of Nigeria.

\section{The contributions of Revd Canon James Adedeji Okuseinde to the expansion of Christianity in Ibadanland}

\section{Birth, education and ministerial background}

In a report forwarded by Stephen Neil to the International Missionary Council in 1950 (Neil 1950:659), Adedeji Okuseinde was described as the real hero of Christianity in Africa. He was one of the great and dynamic indigenous priests in the history of Christianity in Ibadan, and was also seen as a revered indigenous priest of St Peter's Church (now Cathedral), Aremo, Ibadan. James belonged to West Equatorial Africa. ${ }^{1}$ This larger-than-life indigenous figure was born in the Yorubaland on 31 March 1860 to Mr and Mrs James Ojo Okuseinde, a member of the renowned party of Church Missionary Society (CMS) pioneers of seven, known as 'Esin sikeje', meaning 'a horse made the seventh', who brought Christianity into Ibadan in 1851 (Lasebikan 2003:39). Other members of the party were March, Dalley, Daniel Olubi, David Hinderer and Charles Philips. Immediately after his elementary education, James proceeded in 1876 to the CMS training institution, which was later known as CMS Grammar School, Lagos. During his teaching career, James Okuseinde worked as a teacher at Breadfruit School and St Peter's Faji, Lagos, and as a tutor in the CMS institution. Eventually, James Okuseinde gave up teaching for evangelistic duties and was appointed as catechist to Abeokuta, where he served for 7 years (18851892). After his father, who was the indigenous catechist in charge of St James Ogunpa (now the Cathedral of St James the Great, Oke-Bola), Ibadan, died, he was transferred to Ibadan to succeed him at St James Ogunpa (Lasebikan 2003).

\section{Ordination and missionary activities}

Reverend Canon James Okuseinde was ordained into Holy Orders of the CMS with Revd Oyebode by Bishop Tugwell after receiving his theological training under the tutelage of David Hinderer (St Peter's Church History Commission 1987:56-57). His diaconate ordination took place on Epiphany Day, 06 January 1895, which was the first ordination held in Ibadan since the emergence of Christianity in 1851. Three months later, immediately after his priesthood ordination, James Okuseinde was posted to St. Peter's Church, Aremo, Ibadan, where he served for a long and meritorious period of 40 years (1987). He was later admitted into the priesthood at Christ Church, now Cathedral Church of Christ, Marina, Lagos, in February 1897 (Lasebikan 2003), by Bishop Oluwole. ${ }^{2}$ This was a period when the competence of indigenous priests was very much in doubt. The exit of Revd

1.Church Missionary Society, 1805, Register of Missionaries: clerical, lay and female and native clergy from 1804-1904, Church Missionary Society, London.

2.Church Missionary Society, 1805, Register of Missionaries: clerical, lay and female and native clergy from 1804-1904, Church Missionary Society, London.
Thomas Harding from St Peter's gave him the unique opportunity to serve among the people. He was ably assisted by an African catechist. Okuseinde was one of the two black pioneer missionaries who served in St Peter's Church, Aremo, Ibadan (St Peter's Church History Commission 1987:56-57). In 1908, James Okuseinde visited England in the company of the late Revd E.W. George and Revd E.M. Lijadu as delegates representing the then Diocese of Western Equatorial Africa at the Pan-Anglican Congress held in London. In June 1929, he became a Canon of Christ Church Cathedral, Lagos, and in 1935, he was appointed as Chairman and General Superintendent of the Ibadan Anglican Churches and District by the Bishop of Lagos (Lasebikan 2003). He became a true ambassador of the CMS in Ibadan, where he spent most of his lifetime. The Anglican Church was the major Christian group in Britain, being the official or state religion. Its work abroad was through the CMS, which had links with recent British imperial interference in Uganda and Sudan. Earlier CMS efforts had placed churches, schools and hospitals in West Africa (Green 1998:1). Recently, J. Green observed that the majority of its local leaders, who undertook many of the daily tasks and much of the vernacular teaching, were African. Bishop James 'Holy' Johnson, Revd James Okuseinde, Revd E.W. George, 'a native African from Abeokuta', Canon Wilson, 'an African native', and Bishop Isaac Oluwole were honourably noted by the London press (Green 1998:1).

\section{Strategies for church expansion and growth}

Okuseinde's indelible footprints at Aremo Church are perpetually reminisced. On the assumption of his sacerdotal duties, headopted church planting, educational advancement, socio-political involvement and conflict management as strategies to enhance the progress of the church. He led a group of church leaders to quest for land at Oja-Igbo for the establishment of the Primary School of Aremo at Oja-Igbo. As an educationist, Okuseinde exercised an effective supervisory role over St Peter's School, Aremo and other schools in the rural regions. His enormous contributions to education in Ibadan and surrounding regions earned him the title of an educator and educationist of a pioneering type (St Peter's Church History Commission 1987:56-57). This was corroborated by I.B. Akinyele (Lasebikan 2013:52), who described him as a great indigenous priest, an exemplary leader and a preserver of civilisation who strove to promote the growth and development of Ibadan. He was the first councillor in the history of Ibadan, and through his incentives various places of work like offices, customs and treasury were created. These new developments impressed the Ibadan indigenes resident in Lagos to come back home and work in their city (Akinyele 1959:240). The CMS mission at Ibadan, because of its geographical and organisational separation from Lagos, was largely in the hands of Yoruba and Ibadan catechists, who, during the protracted negotiation surrounding the Kiriji war, acted as a sort of international civil service, translating and writing letters, delivering messages and negotiating differences between the Ibadan chiefs and the British. Their relations to both chiefs and 
British were therefore close. However, at the time of the request of the Ijebu, in return for opening the roads through Ijebu country of Ibadan munitions, the CMS agents, in Christian resignation, left their fate in the hands of the chiefs rather than turning to the British for protection. No stigma of British imperialism was attached to the Christians, and their participation in local affairs was increasingly welcomed. For example, in 1903, Revd James Okuseinde and a layman became official members of the council (Awe 1967:216).

Aside from this, Okuseinde's peace-making efforts in Ibadan politics was commendable. He was noted for solving marriage and land disputes amicably between Christian and non-Christian families. He was also known to have intervened in rifts involving traditional chiefs and white men. For instance, at the Pan-Anglican Congress in London, James Okuseinde demonstrated this peace-loving attitude. He declared that black people had no prejudice against the white Christians in order to correct the impression the white men had nursed for a long time. He asked for the support and sympathy of the people in the Church of England in order that the church in Africa might be properly developed (APA 1908:140-141). As part of his contributions towards Christianity in Ibadan, James Okuseinde took pastoral as a tool for an effective evangelism. It was a habitual practice for him to always seek the welfare of the sick people and bear the responsibility of treating the sick and the victims of the horrible intertribal wars of the times. During his dispensation, the involvement of Christian missions in the establishment of mission hospitals was limited. Thus, it was noted that the victims of the Egba and Ijaye wars coupled with fratricidal wars in Ibadan were his patients. Likewise, as part of his indigenous contributions towards Christianity in Ibadan during his own era, Okuseinde, motivated and supervised the Stone Church from 1905 to 1910, which was dedicated to the memory of Mrs Harding. As a clergyman, Okuseinde was ubiquitous and time conscious, an interpreter, arbitrator and spiritual community leader, who remained a hero of the Ibadan people, who served the people selflessly and who did not want to see any child denied the benefit of education on account of the inability to pay school fees. He was a generous and selfless man (Falayi 2013:18). On 03 January 1939, James Okuseinde was awarded a Certificate of Honour by the Resident in Ibadan in appreciation of his immense contributions to humanity. He was the councillor during the reign of head chief Bale Dada which he extended during the time of Basorun Apanpa.

In order for him to have his own family, Okuseinde married Nancy Wright, the daughter of Revd and Mrs J.B. Wright of St Peter's Church, Faji, Lagos. Their union was blessed with six promising children. These include two sons (Nathaniel Okuseinde and Tunde Okuseinde) and four daughters (Adebiyi, Soares, James and Adeyemi). Okuseinde's first daughter married Revd Canon P. V. Adebiyi of Oke-Ofa Babasale, who happened to be the vicar of Aremo from 1947 to 1956. The incumbent provost of the St Peter's Cathedral, Aremo, Ibadan, is an offshoot of this dynasty. His second daughter, chief Hentietta Titilola Soares, was the pioneer Iyalode of Ibadanland. The Okuseinde dynasty has also produced the most Revd Dr Tunji Lasebikan, the Anglican bishop of Ondo diocese and Archbishop of the Ecclesiastical Province of Ondo, while the third and the fourth daughters married into the well-known Adeyemi family of Ondo (Falayi 2013). Okuseinde's religious activities portrayed him as a man of tact, zeal and great indigenous priest and hero of Ibadan mission.

The son of the great architect and builder Christopher Wren, who designed and built the famous St Paul's Cathedral, London, was once asked where in St Paul's the monument to his father was. Standing under the great dome of St Paul's, he replied: If you will seek his monument, look around you.

Similarly, Revd Canon James Adedeji Okuseinde's work in society, church, town, in all walks of life, his various attainments and contributions to human endeavours, and much more than these, people whom he interacted with and those whose lives he touched are his monuments (Falayi 2013).

\section{The legacy of John Olubobokun in the sustenance of Christianity in Ekitiland His background}

John Olubobokun was one the great indigenous pillars of Christianity in southwestern Nigeria whose efforts were not given due recognition. Isaac Babamuboni, who hails from Iyin Ekiti, has been recognised for his prominent role in the evangelisation of Ekitiland, yet Osewa (Omotoye 1999:124) and Olubobokun (Odofin 1959:7), who also hail from Iyin Ekiti, stand out among the people that worked with Babamuboni.

John Olubobokun was probably born in the 1870s to the Odofin family of Iyin Ekiti. Although no one is certain of the exact year of his birth, the fact remains that John was a young man in his 20s when Babamuboni arrived in Iyin Ekiti in 1894. John was not privileged to obtain a formal education, just like many people at that time. It is reliably documented that Babamuboni taught John how to read and write (Johan Olubobokun, Iyin Ekiti, pers. comm, 26 February 2008). The ability to read and write had a great impact on John's life and endeavours.

\section{Contact with Christianity}

It was during the homecoming of Babamuboni to Iyin Ekiti in 1895 after he had gained freedom from slavery in Ibadan that brought John Olubobokun to Christianity (Odofin 1959). It was, however, John's acquaintance with an envoy of the CMS, Mr J.A. Sowumi, in 1895 that deepened John's commitment to Christianity. Sowumi was on a mission from Ibadan to Ado Ekiti, via Iyin Ekiti. The accommodative spirit 
of the then Odofin Oshipe of Okelawe encouraged Sowumi to preach repentance to the people of Iyin Ekiti. Odofin Oshipe of Okelawe kindly sent Olubobokun with Sowumi after Sowumi had delivered his sermon, so that Sowumi would easily find his way to Ado Ekiti. At the time Olubobokun was sent to lead Sowumi to Ewi's palace in Ado Ekiti, he was a young servant (Omodeowa). Sowumi's visit to Ado Ekiti was in fulfilment of the earlier promise made by the CMS representatives Revds Johnson and Philips, who had been in Ado Ekiti in December 1894 (Adebiyi 2003:47).

\section{Conversion, baptism and confirmation}

Olubobokun was the first convert in 1896 among the people of Iyin Ekiti who came in contact with Christianity; he was also the first to be baptised in 1901 (Odofin 1959:20). He had his confirmation a year after at Emmanuel Anglican Church, after which he became the first lay reader in Emmanuel Anglican Church. He was a lay reader ${ }^{3}$ until 1929, the year his uncle, Odofin Osipe, transited into glory. The people of Iyin Ekiti mounted pressure on him to become the Odofin in the place of his late uncle.

\section{Travails as a young convert}

Just like the early Christians in Rome, John Olubobokun faced diverse trials after he became a follower of Christ. A few such challenges that could be described as 'persecution without and persecution within' (John Olubobokun, Iyin Ekiti, pers. comm. 26 February 2008) would be briefly discussed below.

In 1900, just 4 years after Olubobokun's conversion, he was bitten by a poisonous snake. As was the practice of the people at that time, the native doctors were called upon to fetch a medicine that would neutralise the poison in the bite. None of the native doctors heeded the call simply because John had become a Christian. They scornfully responded that 'the God he serves should take care of him' (John Olubobokun, Iyin Ekiti, pers. comm. 26 February 2008).

John was in pain for 16 days before he received a miraculous healing; he did not need to apply any herbal medicine. This divine intervention strengthened his faith and the faith of some Christians in Iyin Ekiti at that time. The unbelievers also saw the surpassing power of the God that Babamuboni and Sowumi had preached about.

Secondly, Olubobokun faced some persecution from those of his own family; this persecution was instigated by Oluboboku's uncle. They alleged that Olubobokun was lazy and that he hated the idols that his fathers worshipped. Typically, Christians at that time were often deemed lazy because they observed Sunday as a day of rest. To others, Christians observed this day of rest to dodge responsibilities. The second allegation was, however, a weighty one. To the

3.In Anglican Church setting, a lay reader or lay preacher assists the incumbent clergy in visiting members, reading scriptural passages and occasionally in preaching the word of God. people, Olubobokun's supposed abandonment of the idols was a stance against his family because idols were perceived then to be the harbingers of fortune and wealth. Consequently, Olubobokun, who was already an adult at this time, was tied hands and legs and was beaten by his family members. The beating was done to dissuade him from being a Christian (Pa S.O. Owoeye, Iyin Ekiti, pers. comm., 03 March 2007).

Soon afterwards, his uncle, having realised that Olubobokun was not dissuaded after the public disgrace, made up a story about a loan of 3 pounds owed by Olubobokun's father, which had to be paid by Olubobokun. Olubobokun pointed out that it was out of place for the one who inherited his father's property, 14 wives, 10 children and five slaves to bring up the issue of an insignificant loan. Olubobokun soon realised that his uncle brought up this allegation only to humiliate him because he observes Sunday as a day of rest when he was not a dead man, for non-Christians believed that only the dead was free from all work and obligations. Olubobokun then began to look for the means to pay the purported loan.

Olubobokun visited catechist J.A. Sowumi in Ado Ekiti on 17 August 1901, where he told Sowumi of his desire to embark on a journey to Ijebu (Ogun State) for the purpose of engaging in menial jobs that could provide him with the funds to pay the loan. To his dismay, Sowumi responded that he would lend him the 3 pounds while Olubobokun serves him for 3 years. ${ }^{4}$ Whenever Sowumi was not around, Olubobokun attended to the people who came for prayers. In addition, Olubobokun was given the responsibility of conducting the daily morning prayer. It is little wonder then that Bishop Philips gave Olubobokun the license to practice as the first lay reader in Emmanuel Anglican Church, the very day he had his confirmation in 1902.

\section{Severe persecution in Ado Ekiti}

During the first decade of the introduction of Christianity, Christians in Ado Ekiti experienced a baptism of fire, reminiscent of what the early church faced in Rome. Olubobokun's case is especially grave because he faced various attacks from the adherents of traditional religion, especially because he was a teacher of the word.

To substantiate the above assertion, consider an incident that happened in 1912. The adherents of traditional religion acted contrary to the order of the king, Ewi Aladesanmi I of Ado Ekiti, but went ahead to beat Christians publicly. Then on 12 June, a woman named Esther Osunyemi was severely beaten for her refusal to give money to a masquerader. The masquerader, known as 'Abolohunku', ${ }^{5}$ acting true to his name, stripped Osunyemi naked. She then ran to the mission house to report the case to Revd Harding.

4.Such service in the vicarage (mission house) included domestic chores, farming for the missionary and assisting in tidying the church's surroundings.

5.Abolohunku is a name given to the masquerader because of his habit of forcing people to give him something substantial. 
Reverend Harding had an appointment at Ilawe Ekiti which prevented him from handling the case. He delegated Olubobokun to follow Osunyemi and recounted the case in the hearing of Ewi Aladesanmi. On the way to Ewi's place, the masquerader, who had hidden all along, emerged from his hiding place and attacked both Olubobokun and the woman. To implicate Olubobokun, those who were around alleged that it was Olubobokun who beat the masquerader. This, of course, was a grave offence because masqueraders are believed to be the custodians of the culture of the people. Any attack on a masquerader was tantamount to going against the cultural norms of the land. An angry mob vented their anger on Olubobokun; they beat him with various items so much that he fainted for a long period. He was resuscitated afterwards and detained at Ewi's palace. Olubobokun was hit with an object on the head and he felt this pain for the rest of his life (Odofin 1959:16-17).

The news about the attack on Christians by non-believers soon spread to other towns and villages. When Revd Harding returned to Ado, he went straight to Ewi's palace to seek Olubobokun's release. When the king was hesitant to release Olubobokun, Revd Harding threatened to involve the colonial government in the matter should Olubobokun die (interview with Chief Dorcas Omotoba, 88 years, Oketoro, Iyin Ekiti, pers. comm., 10 October 2010). The Ewi then reluctantly released Olubobokun to the missionary. As Revd Harding took Olubobokun away for treatment, the people yelled at him. The pain Olubobokun felt confined him to bed for days and it was not until 3 months after that he was able to resume church activities, farming activities and domestic chores.

Such were the persecutions that John Olubobokun faced for embracing Christianity. In spite of these challenges, he remained unwavering and determined to follow Christ. He remained focused on his spiritual activities until July 1929, when he ascended the throne of the Odofin of Iyin Ekiti. It must be noted that when he was being pressured to take up the position of the Odofin of Iyin Ekiti, Olubobokun repeatedly told the people that he would not compromise regarding the traditional practices that would jeopardise his Christian convictions. This condition was accepted by the people before he agreed to ascend the throne.

\section{Socio-religious legacies in Ekiti}

Through divine inspiration, Olubobokun in 1947, he championed the relocation of Iyin Ekiti from its previous segmented settlements (in Odoro, Okesale, Okotoro and Okelawe) to where Iyin Ekiti is today. Olubobokun, propelled by the revelation that he had that there was a demonic covenant plaguing the settlements that made up Uyin, advocated for a change of name from Uyin to Iyin, which means 'the shout of praise day and night', in 1949. To validate his convictions and divine mandate, Olubobokun was the first individual to build a house and settle in the present Iyin Ekiti.
Olubobokun's divine mandate was also felt at Ado Ekiti and Igbara Ekiti, where he suggested that the name 'Ado' should be changed to 'Ade', which means 'crown', and 'Igbara' to 'Igbala', meaning salvation. Although the people of Ado Ekiti and Igbara Ekiti did not agree to the name change, about 40 years later, the authority of the Anglican Church in Ekiti State would eventually create Igbala Otun Archdeaconry, ${ }^{6}$ meaning 'new salvation district'.

John Olubobokun bequeathed a legacy of Christian standard not only in Iyin Ekiti but also in Ekitiland. The fruit of his legacy manifests in the emergence of many Christian Obas in Ekitiland. These are determined not to compromise their faith with ungodly traditional practices. The latest of such was the present Oluyin of Iyin Ekiti, Oba (Justice) Ademola Ajakaye, a staunch Anglican who decided to have his investiture ceremony conducted in the church (All Saints Anglican Church, Iyin Ekiti) ${ }^{7}$ (John Olubobokun, Iyin Ekiti, pers. comm. 26 February 2008), instead of shrine in the forest according to the tradition of the people.

\section{Conclusion - John Olubobokun}

The persecution experienced by John Olubobokun might not be unconnected to his relationship with Babamuboni (the Apostle of Christianity in Ekitiland), who was from the same town as he. Babamuboni in 1896 instructed the Ewi to stop wearing his cap in the church so as to honour God, the King of kings. The people of Ado Ekiti saw this as disrespect from an ordinary evangelist from Iyin Ekiti, a suburb of Ekitiland.

It is therefore not far-fetching to think that John Olubobokun's activities would be taken with all suspicion, which should be curtailed. After his death on 31 October 1969, John Olubobokun was considered by many as a pillar of Christianity in Iyin Ekiti and its environs.

\section{The significance of Thomas Walter Bako to the consolidation of Christianity in north central Nigeria}

\section{Introduction - Thomas Walter Bako}

The scholarly works on the lives and contributions of early indigenous missionaries in Nigeria will not be complete without adequate documentation on Thomas Bako, an Oworo Yoruba (Isichie 1995:172), the patriarch of the great Bako family martyrs in the history of the Anglican Church in Kogi and Kwara states, whose name is in the 'book of Martyrs' at St Paul's Cathedral, London, as the first canonised martyr from this part of the country.

6.An archdeaconry is an area comprising many churches under the supervision of an archdeacon. The area is carved out for administrative convenience in a diocese.

7.See the Log Book of All Saints Anglican Church, Iyin Ekiti by Ven. Bode Otenaike, Vicar in 2005. 


\section{Early life and education}

Although there is no specific record of Thomas Walter Bako's birthdate, it should have occurred around the middle of the 19th century. This assertion is based on his autobiographic statement that at the age of 6 , he was sold into slavery in Lokoja by the Nupe slave traders around 1866. Bako was rescued by the abolitionists and brought up under the supervision of Revd T.C. John, a CMS worker in Lokoja (Banfield 2002:16).

Bako had a brief education in Lokoja before he was sent to Lagos in 1877 where he attended the CMS training institution run by the Collmers. While in Lagos, Bako met Deborah Victoria, whom he later married. On completion of his missionary training in Lagos, he was sent back to work in the confluence area, the headquarters of Niger Diocese, during the episcopacy of Bishop Ajayi Crowther.

\section{The missionary significance of Thomas Walter Bako}

The significance of Bako to the expansion of Christianity is evidenced in his missionary enterprises, his command of different languages and charisma to conduct negotiations between the local chiefs and missionary expeditionists. The missionary activities of T.W. Bako, which started at Kippo Hill in 1883, were noticed in Igbirraland, Umueisha and Koton-Karfe. In fact, he was one of the major role players in the Niger party moving round with Bishop Ajayi Cowther. His ingenuity was noticed to the extent that he also served in Bishop Tugwell's party on the mission from Lagos through Zaria to Kano in 1900 (Walker 2002:14). This team consisted of Tugwell, the trio of Tripoli-trained missionaries (i.e. Revd J. Claude DudleyRyder, Revd A.E. Richardson and Dr W.R.S. Miller), Mr J.R. Burgin, a lay missionary, and Bako. Bako was considered invaluable to this Hausa mission; Nott wrote about him as follows: 'if Miller is to go to Katsina, he must have Bako' (Walker 2002:14).

Bako's geographical knowledge of the terrain of the Northern areas, and his command of at least eight languages apart from English, Nupe, Yoruba, Igbirra and Hausa led him to become an interpreter to the missionaries, not only for religious purpose but also for security reasons. Bako rendered splendid service in obtaining information and in conducting negotiations with the chiefs through whose villages or towns the expedition passed.

Furthermore, Bako proved his worth and resilience when the party met stiff opposition in the north and the lives of European members of the party were in danger at Gierko because of the unfavourable climate. Walker reported that they were nursed by Burgin and Bako (Walker 2002:14). This determination for the expansion of Christianity might have accounted for Aitken's remark: 'Please let me say and say once for all, we cannot absolutely, as far as I can see, give up Bako' (Isichie n.d.:12).

\section{Denial of ordination}

Despite his acclaimed dedication to the work of mission, which resulted in the emergence and growth of many new stations in the confluence area, coupled with his ingenuity and commitment, which made even some European missionaries to heap superlative attestations on him, it is unfortunate that when Bako was recommended for ordination in 1896, racism by the white authority prevented him from being admitted to the Holy Order (Isichie n.d.:13). The only excuse given by people like Bishop Tugwell was that Bako needed more testing to prove his faithfulness and consciousness; hence, his application was delayed. One may not feel comfortable with the flimsy consideration advanced by Tugwell because 19 years were too long to test the commitment of a man who on many occasions left his family in Lokoja for the sake of the Gospel and even risked his life when he had to accompany the Hausa party at a time that the Northern Emirs showed great apathy to Christian evangelisation. Besides, the recommendation by other European missionaries, especially Revd Dobinson, lent credence to the fact that Bako was unnecessarily denied of ordination. In his letter, Dobinson wrote about Bako (Akamisoko 2002) as follows:

A very faithful servant of the society for many years and all of us here rejoice to think he may be admitted to Holy Orders in due course. (p. 80)

The negative disposition of Tugwell towards Bako is reminiscent of what Ajayi Crowther suffered at the hands of some European missionaries, especially Henry Townsend (Omoyajowo 1995:32). This attitude emanated from the error of judgement by some white missionaries that Africans lacked acumen for leadership; therefore, they should be placed perpetually under white domination. In fact, Isichie mentioned that one gifted Isaac Mba, the first Niger Igbo agent, was forced to resign as a result of European prejudice, but Bako remained undaunted.

\section{Bako's martyrdom}

There are various accounts regarding the factors that led to Bako's death. One account states that he was shot with poisoned arrows by some robbers during one of his missionary journeys in 1902, which resulted in his untimely death (Isichie 1995:172). However, Isichie (1995:172), Banfield (2002:12), Fabuluje (n.d.:5) and George Bako (Banfield 2002:13) all posited that Bako was shot dead with arrows while on missionary journey at Tawari, Koton-Karfe, near Lokoja. As it was customary for Bako to preach from village to village, he and two of his team members (one of whom was Ogbeha) were attacked. Although his companions escaped and ran to Umueisha, he was shot both in the leg and in the neck and was left alone to bleed throughout the night 
(Ezebube 2000:75). Eventually, Mr Aitken, based on the report from Bako's boys, came to carry him to Lokoja, where he died on the fourth day.

The British Government took drastic action against the natives Tawari by sending soldiers to the town who burnt it to ashes, including all the farm products. The village head was also taken to Lokoja to serve a jail term (Banfield 2002:16).

The martyrdom of T.W. Bako recalled the fate suffered by early missionaries. Although some of them were flogged and imprisoned, others were killed, but their blood continued to serve as the seed of the gospel.

The rigorous labour of Bako and his valiant death for the advancement of Christianity earned him unique recognition in the Hall of Fame of the Anglican Church. Bako did not labour in vain as a missionary. Although he died as an evangelist, he was divinely compensated with many pillars of the church, including late Revd Canon J.A. Bako (one of his children), Rt Revd George Bako (a grandchild) and Rt Revd Josiah Idowu-Fearon (a greatgrandchild), who is the Secretary-General of the Anglican Communion worldwide, and a host of other achievers in other walks of life.

\section{Conclusion}

It is no gain saying that the trio discussed left indelible legacies in their generations, which had and still have a far reaching impact on their communities. Okuseinde s sociopolitical relevance was felt in the areas of welfare of the sick, education for indigent student, intervention in land disputes among Christians and non-Christians as well as rifts involving the traditional chiefs and the white men.

For Olubobokun, Iyin-Ekiti ingigenes will forever be indebted to him for relocating them from their segmented settlements to its present location. In addition, his unique policy as a Christian king has been imbibed by the present ruler of IyinEkiti who had his investiture ceremony (crowning) done in the church and refuses to wear his crown whenever he is in the church as a sign of respect to God, the King of kings. T.W. Bako's legacy could be seen in his determination for the expansion of Christianity to the point of taking a risk that eventually claimed his life.

\section{Acknowledgements Competing interests}

The authors declare that they have no financial or personal relationships that may have inappropriately influenced them in writing this article.

\section{Authors' contributions}

S.M.M. wrote on Olubobokun and Thomas Bako, and T.P. wrote on Okuseinde.

\section{Ethical considerations}

This article followed all ethical standards for research without direct contact with human or animal subjects.

\section{Funding information}

This research received no specific grant from any funding agency in the public, commercial or not-for-profit sectors.

\section{Data availability statement}

Data sharing is not applicable to this article as no new data were created or analysed in this study.

\section{Disclaimer}

The views and opinions expressed in this article are those of the authors and do not necessarily reflect the official policy or position of any affiliated agency of the authors.

\section{References}

Adebiyi, P.A., 2003, History of Christianity in Ekitiland, CSS, Lagos.

Akamisoko, D., 2002, Samuel Ajayi Crowther in the Lokoja Area, Sefer Books, Ibadan.

Akinyele, I.B., 1959, Iwe Itan Ibadan ati die ninu awon Ilu Agbegbe re bi Iwo, Osogbo, ati Ikirun, James Townsend, England.

APA, 1908, Congress, Pan-Anglican. 2013. The church's missions in Christendom vol. 6, Forgotten Books, London, (Original Work Published in 1908), see also, MPA, 2013, Congress Pan-Anglican, The church's missions in Christendom, vol. 6 pp. 140-141, 1908, Reprint, Forgotten Books, London.

Awe, B., 1967, The city of Ibadan, Cambridge University Press, Cambridge.

Banfield, A.W., 2002, 'Life among the Nupe Tribe in West Africa', Souvenir Programme for the Centenary Memorial Service of T.W. Bako.

Church Missionary Society, 1805, Register of Missionaries: clerical, lay and female and native clergy from 1804-1904, Church Missionary Society, London.

Deaville, W., 2002, Romance of the Black River, Souvenir Programme for the Centenary Memorial Service.

Ezebube, C., 2000, Chukwurah George Bako (Bishop of Lokoja). The Controversial Foo for Christ, CSS, Lagos.

Fabuluje, J.A., n.d., The history of the Diocese of Kwara, 1974-1999, p. 5.

Falayi, G., 2013, 96th Patronal Festival Celebration, Book Launch and Award Service Program of St Andrew's Anglican Church, Oke-Paanu, Omi-Adio, Ibadan, 30th November.

Green, J., 1998, Black Edwardians: Black people in Britain 1901-1914, p. 1, Frank Cass Publishers, London.

Isichie, E., 1995, A history of Christianity in Africa (from antiquity to the present), William B. Eerdmans, Grand Rapids, MI.

Isichie, E., n.d., 'Biography of Evangelist Thomas Walter Bako - The martyr in varieties of Christian experience in Nigeria', in The Centenary Souvenir of T.W. Bako, p. 12.

Lasebikan, G.J., 2003, 'Canon James Adedeji Okuseinde 1860-1940', in K. Bamgbelu (ed.) 150 years of Christianity in Ibadan: The untold story, Oyo State Government Printing Corporation, Ibadan.

Mukuka, G., 2006, 'Clashes of worldviews in the history of the Catholic Church in South Africa: The struggles of Fr. Aloys Majonga Mincadi with his white superior (1877-1933)', Studia Historiae Ecclesiasticae 32(2), 207-225.

Neil, S., 1950, 'Survey of the training of the ministry in Africa', in B. Sundkler \& C. Steed (eds.), A history of the church in Africa, pp. 76-78, International Missionary Council, London.

Neil, S., 1950, Survey of the training of the ministry in Africa, International Missionary Council, London, quoted in Sundkler and Steed, A history of the church in Africa.

Odofin, J.O., 1959, Iwe Itan Kukuru fun Igbati Oro Olorun de Ile Ekiti ni 1895.

Omotoye, R., 1999, 'The contribution of Bishop Charles Philips to the church, political and socio-economic life in Eastern Yorubaland, (1877-1906)', PhD thesis, Department of Religious Studies, University of Ibadan, Nigeria.

Omoyajowo, J.A., 1995, Makers of the Church in Nigeria, 1842-1947, CSS, Lagos.

St Peter's Church History Commission, 1987, A short history of St. Peter's Church, Aremo, Ibadan (1852-1985), Bolayele Commercial Press Ltd., Ibadan.

Such Service in the vicarage (mission house) includes domestic chores, farming for the missionary and assisting in tidying the church's surrounding. 